\section{International Scientific Journal Theoretical \& Applied Science}

p-ISSN: 2308-4944 (print) e-ISSN: 2409-0085 (online)

Year: $2014 \quad$ Issue: $10 \quad$ Volume: 18

Published: $30.10 .2014 \quad$ http://www.T-Science.org
Elnur Latif oglu Hasanov Corresponding member of International Academy of Theoretical and Applied Sciences, Ph.D. postgraduate Institute of Local-lore of Ganja Branch Azerbaijan National Academy of Sciences, Ganja, Azerbaijan 1-hasan@hotmail.com

\title{
SOME PROBLEMS OF RESEARCH OF HANDICRAFTS BRANCHES OF GANJA OF THE END OF XIX - FIRST HALF OF XX CENTURIES
}

Abstract: In a life of the population of Ganja the role of craft products was great during XIX-XX centuries. In this scientific work the main moments of historic-ethnographical importance of development of the main traditional branches of craftsmanship of Ganja for the first time has been systematic investigated on the basis of innovative technologies and facts. Also were researched the basic skill characteristics of different wares of these traditional handicraft branches.

Key words: handicraft traditions, Ganja, XIX-XX centuries, historic-ethnographical research, Azerbaijan.

Language: English

Citation: Hasanov EL (2014) SOME PROBLEMS OF RESEARCH OF HANDICRAFTS BRANCHES OF GANJA OF THE END OF XIX - FIRST HALF OF XX CENTURIES. ISJ Theoretical \& Applied Science 10 (18): 17-20. doi: http://dx.doi.org/10.15863/TAS.2014.10.18.4

\section{Introduction}

Research of traditional wares of handicraft kinds of Ganja of the XIX-XX centuries on the basis of innovative methods is very important and necessary. The increase in quantity of handicraftsmen in a city directly has been bundled to population growth. Closely bundled to an economy and a daily life of the people, craft employment were one of the basic carriers of national traditions. The competition of production of production plants and factories has not reached still serious level and consequently was created a favorable condition for spreading of traditional occupations there. In addition, products of these craft branches have been closely bundled to a life and traditions of the people, and it would be difficult to replace with their factory production (Guliyeva N and Häsänov E, 2014). In the specified period of history in Ganja developed basically carpet weaving, weaver's business, craft of the tailor, squeeze men, forge and a jeweler, trades of dyer, the stone mason, the cooper and leather dresser, weapon business and other similar craft branches (Taylor P and Hasanov E, 2013).

\section{Materials and methods}

During our researches in 2012-2013 years we determined some new scientific arguments and facts in this field.
Historic and ethnographic exploration of problems and branches of crafts is very important, as a way of studying along with history and culture of the people, years generated political-economical and relations of production. These products were widely used inhabitants of Ganja they decorated conditions of living rooms, with them filled up a dowry of brides. The dresses created in local departments, suits and caps were an integral part of an attire of towndwellers. In comparison with villages though the national clothes in XX century began to supersede them gradually. It also has been bundled to accruing arrival to Ganja representatives of other nationalities. Therefore changes in clothes were more marked. Only female ornaments as an attire constituent part left the national feature. At this time there were fashionable ornaments on a breast, hands, set pins and on clothes. The increase in quantity of handicraftsmen in a city directly has been bundled to population growth.

Tailors and hatters created both national clothes, and clothes in style of the European fashion. According to the spent explorations there are exact data on wide development of a jeweler in Ganja in the end of XIX century - in a beginning of XX centuries. Jewelers basically fabricated ornaments to order. Among them there was a specification. Jobs of skilful masters amazed even foreigners. Development of trading and economic relations of Ganja with the next 
states promoted recognition of local jewels abroad (Ahmadov F, 2007). From the point of view silkworm breeding development and it's preparing technology there were two main forms of production: so-called raw silk weaving and felt weaving. There were made such kind of important samples of art as atlas and kelaqai (silk kerchief) (Nishiaki Y and Hasanov E, 2014). We must pay attention to the moment that differs from the other silk fabrics, kelaqai was prepared by specialists. But distinctly of production of raw silk that was city silkworm breeding and was man activity, felt production was woman work. In Ganja, that know as the ancient cultural center, the saddlemaking handicraft differed from others with rich old traditions. First time preparation of the vehicles was house profession. But afterwards saddle preparation needed of qualified skilled masters, so a new type of art saddle-making, started to form. Historically the traditional art of saddle-making in Ganja developed in direction of cargo and passenger saddle making. The art of saddle-making within the local saddle-types and their components were determined on a specialization. The production of cargo or pack-saddle a rule was engaged by pack-saddle maker. For this reason, in most cases, the profession was called trade of packsaddle maker (Ahmadov F, 2007).

All the glass dishes found in and around Ganja are similar with the local clays on decoration of that period. Glass dishes were containing of Iron, cobalt, magnesium and other elements, that were specific elements for Ganja and its surroundings. The development history of this sphere of craftsmanship can be determined only through archaeological research. In general, information about the development of this sphere of was found in 1959-1960 years, glass products in and around Ganja was obtained only at the end of the twentieth century.

Distribution of experts of certain crafts on quarters and neighboring communes was prominent of crafts. For example, it is possible to recollect. In these neighboring communes functioned craft departments. On a ground classifying crafts it has been defined that by the end of XIX century a number of fashionable trades began to disappear. They have got rid of and have been replaced by representatives of new crafts (Hasanov E, 2014).

\section{Discussion of results}

1. In whole at the beginning of XIX- XX century the quality of carpet craftsmen were more than $\mathrm{XX}$ thousand. Such kind of carpets without pile as phalas, kilim, holdall, bead, verni, sumach, heybe, carpet - bag were different with qualities and colored ornamental elements. Especially we must say that Ganja carpets have always been valued for its quality and art characteristics. As the result of in XIX - XX centuries most of Ganja carpets were showed in world in fluent exhibition. Ganja carpets were showed and highly in international exhibition. Nowadays, Ganja's carpets are kept in authoritative museums of world, and also in collection of different people. The studying of Ganja's carpets for art characteristics quality form science point of view is very important for investigation heritage of world culture (The dawn of Art. 1974).

2. Wood treatment products historically have been represented in various fields of social and cultural life in Ganja as the kitchen appliances: trough, quadruped, rolling-pin, mortar and pestle, ladle, spoon, trough, also transport means: sleigh, car, and ski. Weaving tools: comb, face. Household tools: harrow, wooden plow, threshing board, spade, wooden shouvel, pitchfork and rake. Musical instruments: saz, ud, tar, chamahcha, tambourine, drum (Guliyeva N and Häsänov E, 2014).

3. The craftsmanship of carpet-making is one of the important cultural achievements of the Eastern people in Azerbaijan production of carpets appeared during I millennium BC. But carpet-making in the first period of Middle Ages has turned to the independent sphere of craft. In Ganja, that has minimum 4000 years history, production of carpets differed with quickly development. In this ancient city, that is native land of great Azerbaijani poet and thinker Sheikh Nizami Ganjavi, were weaved very uncial, inimitable kinds of carpet. In Ganja, that has rich traditions, were prepared carpets with various characteristics. For this reason one of Azerbaijani carpet groups are Ganja carpets or (Ganja-Kazakh carpets). Pay attention that in Ganja namely local kinds of carpets-palaz (carpets without of pile) are weaved (Hasanov E, 2014). These carpets that are producing by local inhabitants are differing with specific handicraft features. Majority of local wool products, richness of natural colors and existence professional carpet-making women made for quick development carpet making craftsmanship in Ganja and in its surround territories.

4. Made of precious metals gold and silver jewelries, that prepared by Ganja masters, are divided into 4 main groups for wearing and putting: Neck jewelries - it is included such kind of jewelries, that gold piece coin, imperial, cardamom or barley, medallions, bracelets, different kinds of beads and etc., jewelries for arms and fingers - this group include bracelets, bangles and rings with various precious stones as (turquoise, rubies, pearls and etc.), head jewelries - skull-cap and others, jewelries for clothiers (Taylor P and Hasanov E, 2013).

5. From the construction point of view, samples of pottery, that concern to Antique period, also to the period of Hellenism in Ganja, differed in various forms as pictorial vases, ceramic figures, connected dishes. During the end of Middle Ages and New Period in Ganja and its regions ceramic has following kinds as building ceramic materials, unglazed ceramic products, glazed ceramic products. For Middle Ages and New period among pottery products of Ganja 
ceramic samples as clay construction materials have great importance. First of all, glazed bricks that used in construction of most buildings in the XVII-XVIII centuries, and also in great monuments and the main construction material - air-dried bricks, attracted attention. In addition to the found samples in residential areas as a result of archaeological excavations, also were found a lot of brick spoilages. According to such kind mass finding of brick spoilages, we can make the conclusion, that the bricks used in construction of buildings in Ganja, were wares of local production (Azerbaijan ethnography, 2007).

6. The formation of pottery on the territory of ancient Ganja is concern to the stages of ancient history. Basis on research works carried out by the various persons in XIX century and expertsarcheologists at the beginning of XX century in old ruins of the city and surrounding areas there were found different samples of pottery. In the first half of the XVIII-XIX centuries, as well as in other parts of Azerbaijan, in Ganja household objects, forging weapons and jewelries that made from metal were decorated with different technical ways. As in many places, production of wool, cotton and silk in and around Ganja made necessary emergence and development of weaving. Becoming weaving one of the ancient spheres of crafts in and around Ganja was connected with the rich raw material base here. Presence of useful plant species for textile, including cotton, high level development of wool area of agriculture-sheep and goat breeding, camel breeding, horse breeding, presence of cotton cropping in Middle Ages and finally, regular expansion of silkworm breeding in this area created a foundation for growth of weaving here (Burton-Brown T, 1951). In addition, during the research work in Ganjabasar and other territories monuments there have been found whole and parts of weaving loom and different sizes of clay and bone samples that consist to weaving (Hasanov E, 2013). Traditional spheres of crafts are invaluable and reliable sources of studying of culture, aesthetic taste, outlook (world outlook) of the Azerbaijan people.

\section{Conclusion}

1. Internal conditions of craft department reflected a sort of employment of his owner. In these departments worked the master and his pupils. In a life of the population of Ganja the role of craft products was great. These products were widely used inhabitants of Ganja they decorated conditions of living rooms, with them filled up a dowry of brides. The dresses created in local departments, suits and caps were an integral part of an attire of towndwellers. In comparison with villages though the national clothes in XX century began to supersede them gradually. It also has been bundled to accruing arrival to Ganja representatives of other nationalities. Therefore changes in clothes were more marked. Only female ornaments as an attire constituent part left the national feature. At this time there were fashionable ornaments on a breast, hands, set pins and on clothes (Häsänov E, 2014).

2. Investigation of the main traditional craft branches on the basis of new, innovative methods and technologies is very important. Results of these researches show the significance of different patterns of craftsmanship kinds as a source in studying of historical past of nations.

3. Studying of craft problems actually and in the modern world in sense of the decision of professional problems. From the investigated national employment carpet weaving, the jeweler, a stone dressing and strenuously develop on the basis of ancient traditions already dying out ancient trades, such as a pottery and an art embroidery. Each area of Azerbaijan possesses characteristic environmental resource bases for it and it promoted development of various crafts. Thus, a number of employments in Ganja, during the period since XIX century to the middle of XX century, differed from crafts of other areas of the country. It was first of all the trades bundled to a spreading of a city and population grown has increased demand for craft products. Under such circumstances the handicraft work could not keep the natural character (Azerbaijan ethnography, 2007).

4. In traditional production of cloth manufactory trade historically played an important place. This kind of craft that developed on the basis of local raw materials was tied with cotton-growing economy. Since the time of the early Middle Ages, Ganja as other big cities has been the main center of Azerbaijan in production of cotton cloth. In this ancient city printed cotton and calico fabrics have been widely produced. In traditional cloth productions the main place took the urban mines (Smith W and Hasanov E, 2013).

Investigation of traditional wares of handicraft kinds of Ganja on the basis of innovative methods is very important and necessary. During our researches in 2012-2013 years we determined some new scientific arguments and facts in this field and in the future we shall continue our investigations.

\section{References:}

1. Qasımov M, Quliyev H (1986) Qədim xalq boyama üsulları. Qobustan, № 1 (69). Bak1, 1986.
2. Abdullayeva M (2004) Azərbaycan zərgərləri. Bak1, 2004. 
3. Ohmədov FM (2007) Gəncənin tarix yaddaşl. Gəncə: Elm.

4. Bünyadov TӘ (1964) Qədim Azərbaycanda toxuculuq və keçəçiliyin inkişaf tarixinə dair. Azarbaycan Etnoqrafik Macmuəsi, I bur., Bak1.

5. Bünyadova ST (1992) Nizami vo etnoqrafiya. Bakı: Elm.

6. Burton-Brown $\mathrm{T}$ (1951) Excavations in Azerbaijan, 1948. London

7. Ergenekon C (2005) Innovative skill methods in carpet-making trade and contemporary approach to this field. Proceedings of the III International symposium on the theme of Carpet and traditional handicraft of Azerbaijan. Baku: Science, pp. 45-46.

8. Ofəndiyev RS (1966) Azarbaycanın badii sanatkarlığı. Bakı: Azərnəşr.

9. Guliyeva NM, Häsänov EL (2014) Die traditionelle Gändschänischen Teppiche von Zeitraum der Aserbaidschanischen Gelehrten und Dichter Mirsä Schäfi Waseh als ethnoanthropologische quelle (XIX Jahrhundert). European Applied Sciences, 2: 3-5.

10. Hasanov EL (2013) About fundamental studies on local cultural traditions of Ganja. European Journal of Natural History, 3: 65-68.

11. Hasanov EL (2014) Approccio innovativo per lo studio scientifico delle tradizioni artigianali grandi Ganja seconda metà del XIX-inizi XX secolo. Italian Science Review, 4: 642-645. Available at URL: http://www.iasjournal.org/archive/2014/april/Hasanov.pdf

12. Həmidova İ (2000) Azərbaycan parça sənətinin tarixi inkişaf yolları. Elmi axtarışlar, VIII toplu, Bak1.
13. Hovilov HA (1991) Azarbaycan etnoqrafiyast. Bak1: Elm.

14. Häsänov EL (2014) Ethno-anthropologische merkmale der Gändschänischen Teppiche von XIX-XX jahrhundert (auf die 220-jährige jubiläum der Aserbaidschanischen gelehrten und dichter gewidmet Mirsä Schäfi Waseh). Austrian Journal of Humanities and Social Sciences, 1: 3-7.

15. Nishiaki Y, Hasanov EL (2014) About ethnoarchaeological and anthropological research of some prehistoric monuments of Ganja. Theoretical \& Applied Science, 1(9): 45-48. doi: http://dx.doi.org/10.15863/TAS.2014.01.9.8

16. Smith W, Hasanov EL (2013) Importance of handicraft traditions in investigation of history of urban culture in Ganja. Theoretical \& Applied Science, 11(7): 61-66. doi: http://dx.doi.org/10.15863/TAS.2013.11.7.10

17. Taylor PM, Hasanov EL (2013) Ethnological features of cultural heritage of Ganja (On the basis of Mahsati Ganjavi's creation). Theoretical \& Applied Science, 12(8): 41-44. doi: http://dx.doi.org/10.15863/TAS.2013.12.8.10

18. Tərlanov M, Ofəndiyev R (1960) Azarbaycan xalq sənəti. Bakı: Uşaq gənc nəşr.

19. The dawn of Art (1974) Russia: Aurora Art Publishers.

20. Ofəndiyev RS (1980) Azarbaycanın badii sənətkarliğı dünya muzeylərində. Bakı: İşıq, 1980. 